Article

\title{
The Application of the Environment Act 2021 Principles to Car- bon Capture and Storage
}

\author{
Angelica Rutherford
}

School of Law, Liverpool Hope University, UK.; Archbishop Desmond Tutu Centre for War and Peace Studies; ruthera1@hope.ac.uk

\begin{abstract}
Carbon Capture and Storage (CCS) is a new technology considered to have the potential to decarbonise economies. However, nationally and internationally the use of CCS has also been raising concerns about its potential global risks and adverse impacts on the environment. CCS was part of the discussions at the 4th United Nations Environment Assembly (UNEA) in March 2019 and in side-events in the 26th UN Climate Change Conference which took place in Glasgow in November 2021. The UK Government aims to deploy CCS at scale during the 2030s, subject to cost reduction. At the same time the UK Government has recently enacted the Environment Act 2021 which provides a set of five environmental principles: the integration principle, the principle of preventative action, the precautionary principle, the rectification at source principle and the polluter pays principle. This work seeks to analyse the application of the UK environmental law principles to carbon capture and storage policies in the UK and its balance with other considerations. Given the concerns surrounding the use of CCS, the debate about its legality may arise in the UK and in other countries. To this end, this paper initially carries out a systematic review of CCS policy documents to discover the policy considerations which support the development of CCS. It then examines the application of the UK environmental law principles to CCS initiatives and its balance with other considerations, such as reduction of carbon emissions, security of energy supply, economic growth and technological leadership. In doing so, this paper aims at contributing to the debate surrounding recent technological developments which have been utilised to help address climate change and some of the legal challenges emerging through the use of CCS under UK environmental law.
\end{abstract}

Keywords: environmental law principles, carbon capture and storage, energy, climate change.

\section{Introduction}

The increase of concentration of greenhouse gases (GHGs), particularly $\mathrm{CO} 2$, has been associated to climate change and global warming. As a result of the negative impacts of carbon-intense economies, low-carbon technologies have been developed to reduce $\mathrm{CO} 2$ concentration both in the atmosphere and in flue gas emissions. Carbon capture, utilisation and storage (CCUS) applied to biomass, hydrogen and fossil fuels is part of a portfolio of mitigation options which countries have been relying on to achieve ambitious climate goals set under the Paris Agreement in 2015. It was part of the discussions at the 4th United Nations Environment Assembly (UNEA) in March 2019 (Tollefson 2019) and in side-events in the 26th UN Climate Change Conference which took place in Glasgow in November 2021 (IEAGHG 2021)

Carbon capture and storage (CCS) consists essentially in capturing the carbon dioxide produced through the combustion of fossil fuels in power stations and in a variety of industrial processes and storing it permanently in artificial reservoirs such as saline aquifers or depleted oilfields where it cannot enter the atmosphere (IPCC 2005). CCS is typically considered as three independent yet inter-connected steps: (i) the separation and 
purification of $\mathrm{CO} 2$ from fuels, feedstocks and industrial processes, (ii) the compression and transport of $\mathrm{CO} 2$ by pipeline or tanker to its storage destination, (iii) injection of $\mathrm{CO} 2$ through an oilfield style borehole into microscopic pore space of geological reservoirs of the deep subsurface, where the CO2 will remain in perpetuity (Haszeldine et al. 2018). As of 2020, there were almost 40 commercial-scale CCS facilities in operation worldwide (Global CCS Institute 2020).

Carbon capture and utilisation (CCU) aims to convert the captured carbon dioxide into more valuable substances or products. Another emerging technology that could be utilised to manage carbon emissions is Direct Air Capture (DAC) which captures carbon dioxide out of the atmosphere rather than at the point of emissions, being as such independent of source and timing of emissions (IPCC 2018). Nineteen DAC plants are currently operational in Europe, the United States and Canada. Most of these plants are small and sell the captured CO2 for use - for carbonating drinks, for example. (Budinis 2021). This work, however, focuses on carbon capture and storage (CCS) due to controversies surrounding the environmental benefits of this technology and the more advanced stage of development of commercial-scale facilities in operation when compared with DAC.

Previous scientific literature has identified the need to deploy CCS if society is to transition to a low carbon economy (Kemper 2015; Haszeldine et al. 2018) and this has been confirmed in legal scholarship (Heffron et al. 2018). The latest Intergovernmental Panel on Climate Change (IPCC) Special Report on global warming also includes CCS technologies in all pathways that bring global temperature bellow $2^{\circ} \mathrm{C}$ (IPCC 2018). In the UK, the independent Committee on Climate Change described CCS as 'a necessity, not an option' (Committee on Climate Change, 2019), although this position has been criticised and subject to public opposition (Thomas 2021; Holland 2021).

Internationally carbon dioxide removal technologies, such as CCS, have been raising concerns about their potential global risks and adverse impacts on the environment and sustainable development, and due to the lack of multilateral control and oversight. At UNEA 4, a resolution that would have mandated the United Nations Environment Programme (UNEP) to make an assessment of potential risks and governance needs of geoengineering, including CCS, did not pass (Draft Resolution for consideration for the 4th United Nations Environment Assembly; Xaver Perrez 2020). However, this question may come up again at the Fifth Session of the United Nations Environment Assembly (UNEA5) in February/March 2022 (UNEA 2022).

The need to reduce emissions of $\mathrm{CO} 2$ and other greenhouse gases is recognised by the UK Government in the Climate Change Act of 2008, as amended by the Climate Change Act 2008 (2050 Target Amendment) Order 2019 (S.I. 2019/1056), which sets legally binding targets for the UK to reduce emissions of $\mathrm{CO} 2$ and other greenhouse gases by 100\% from 1990 levels, by 2050.

In its Clean Growth Strategy, the UK has reaffirmed its commitment to deploying CCUS in the UK's major manufacturing and refining areas subject to cost reduction as part of a green industrial revolution and to reach net zero carbon emissions by 2050 (DBEIS 2017). With the aim of becoming a global technology leader for CCUS, the UK Government committed $£ 1$ bn of public funds for a new CCUS Infrastructure Fund to help develop CCUS schemes in Britain (DBEIS 2020). Five eligible CCUS clusters have been announced: DelpHYnus, East Coast Cluster, Hynet, Scottish Cluster and V Net Zero. The ambition is to capture 10Mt of carbon dioxide a year by 2030, the equivalent of four million cars' worth of annual emissions (HM Government 2020). In addition to CCUS, the UK has also recently started to fund projects on Direct Air Capture (DAC). However, there is currently no operational DAC plants in the UK (BEIS 2022).

At the same time the UK Government has introduced the Environment Act 2021 which provides a set of five environmental principles which will guide future policymaking to protect the environment: the integration principle, the principle of preventative action, the precautionary principle, the rectification at source principle and the polluter pays principle. With the enactment of the Environment Act 2021 the UK has a definite catalogue of environment principles set in one document. The aim of this work is to analyses the 
application of these principles to carbon capture and storage (CCS) policies in the UK and its balance with other considerations, such as socioeconomic benefits, security of energy supply and diversity of technologies and fuels. In doing so, this paper aims at contributing to the debate surrounding recent technological developments which have been utilised to help address climate change and some of the legal challenges emerging through the use of CCS under UK environmental law.

CCS is largely absent from the Nationally Determined Contributions submitted by Member States to the United Nations Framework Convention on Climate Change (UNFCCC) in the run-up to COP26 as a type of technology that countries intend to use for implementing adaptation and mitigation actions (UNFCC 2021). It is also lowly ranked in investment priorities around the world (Fridahl 2017), particularly for ramping up large CCS infrastructure (Bhave et al.2017). However, due to international concerns surrounding the use of CCS, the debate about its legality may arise in other countries. Therefore, it is important to learn about CCS policies in the UK and the applicability of principles of environmental law under the Environment Act 2021 as a case study because this may serve as an example to other countries discussing such matters.

This paper is structured as follows. First, in section 2, policy considerations justifying the adoption of CCS in the UK are explored. Next, the application of principles of UK environmental law to CCS is analysed. Finally, this paper concludes and also highlights areas for future research.

\section{Policy considerations justifying the adoption of CCS in the UK}

This section involves a systematic review of CCS policy documents. The guidelines in Rousseau, Manning and Denyer (2008) and in Denyer and Tranfield (2009) surrounding question formulation, location, selection, evaluation, analysis and synthesis of study are observed. Following studies conducting systematic reviews in other subject areas, such as Danese, Romano, \& Boscari (2017) and Nolan and Garavan (2016), a five-stage structured process is adopted. In stage 1 the scope and objectives of the analysis are identified. The primary objective is to investigate the policy considerations used to justify the adoption of CCS. In stage 2 the inclusion criteria are set. The focus is on official policy documents published from January 2009 to October 2021 by the UK Government and its departments. In stage 3 the exclusion criteria are applied. The aim of the research is to analyse CCS policy considerations contained in official government documents. Therefore, firstly, independent and non-UK Government reports are excluded. Secondly, policy documents which do not examine CCS are excluded. In stage 5 the final data is classified into themes based on the focus of the paper.

In total 14 documents were selected and analysed as per table 1. Four themes were identified as policy considerations used to support CCS development: reduction of carbon emissions, security of energy supply, economic growth and technological leadership.

\begin{tabular}{|c|c|c|c|}
\hline $\begin{array}{l}\text { Table 1: Summary of CCS } \\
\text { policy considerations.Document title }\end{array}$ & Department & Year & Policy considerations \\
\hline $\begin{array}{c}\text { Carbon Capture Readiness } \\
\text { (CCR): A guidance note for Section } 36 \text { Electricity Act } \\
1989 \text { consent applications }\end{array}$ & DECC & 2009 & Reduction of carbon emissions \\
\hline $\begin{array}{l}\text { Overarching National Policy } \\
\text { Statement for Energy (EN-1) } \\
\end{array}$ & DECC & 2011 & $\begin{array}{l}\text { Reduction of carbon emissions, secu- } \\
\text { rity of energy supply }\end{array}$ \\
\hline $\begin{array}{c}\text { National Policy Statement for } \\
\text { Fossil Fuel Electricity Generating } \\
\text { Infrastructure (EN-2) }\end{array}$ & DECC & 2011 & Reduction of carbon emissions \\
\hline $\begin{array}{l}\text { The Clean Growth Strategy: Leading the way to a low } \\
\text { carbon future }\end{array}$ & HM Government & 2017 & $\begin{array}{l}\text { Low carbon growth, energy efficiency } \\
\text { and emissions reduction }\end{array}$ \\
\hline $\begin{array}{l}\text { Implementing the end of unabated } \\
\text { coal by 2025: Government response to unabated coal } \\
\text { closure consultation }\end{array}$ & BEIS & 2018 & $\begin{array}{l}\text { Ruled out mandating CCS to be de- } \\
\text { ployed on existing coal power stations } \\
\text { due to high costs, length of time be- } \\
\text { yond } 2025 \text { and inefficiency }\end{array}$ \\
\hline
\end{tabular}




\begin{tabular}{|c|c|c|c|}
\hline $\begin{array}{l}\text { The UK carbon capture, usage and storage (CCUS) de- } \\
\text { ployment pathway: an action plan }\end{array}$ & HM Government & 2018 & $\begin{array}{l}\text { Decarbonisation of economy, contribu- } \\
\text { tion to industrial } \\
\text { competitiveness and generation of new } \\
\text { economic opportunities }\end{array}$ \\
\hline $\begin{array}{l}\text { Carbon capture usage } \\
\text { and storage: third time } \\
\text { lucky? }\end{array}$ & House of Commons & 2019 & $\begin{array}{c}\text { Decarbonisation of economy, economic } \\
\text { growth, job creation, technological } \\
\text { leadership }\end{array}$ \\
\hline $\begin{array}{l}\text { Carbon capture usage and storage: third time lucky? } \\
\text { Government Response to the Committee's Twentieth } \\
\text { Report }\end{array}$ & HM Government & 2019 & $\begin{array}{c}\text { Decarbonisation of economy, economic } \\
\text { growth, job creation, technological } \\
\text { leadership }\end{array}$ \\
\hline $\begin{array}{c}\text { Carbon capture, usage and storage: A Government Re- } \\
\text { sponse on potential business models for Carbon Cap- } \\
\text { ture, Usage and Storage }\end{array}$ & BEIS & 2020 & $\begin{array}{l}\text { Climate change (net zero transition), } \\
\text { economic growth, job creation, techno- } \\
\text { logical leadership } \\
\end{array}$ \\
\hline $\begin{array}{l}\text { Carbon Capture, Usage and Storage: } \\
\text { An update on business models for Carbon Capture, Us- } \\
\text { age and Storage }\end{array}$ & BEIS & 2020 & $\begin{array}{l}\text { Climate change (net zero transition), } \\
\text { economic growth, job creation, techno- } \\
\text { logical leadership }\end{array}$ \\
\hline The ten point plan for a green industrial revolution & HM Government & 2020 & $\begin{array}{l}\text { Enhancement of UK industry competi- } \\
\text { tiveness, job creation, climate change } \\
\text { (net zero transition) }\end{array}$ \\
\hline National Infrastructure Strategy & HM Treasury & 2020 & $\begin{array}{l}\text { Advancement of newer technologies, } \\
\text { job creation, climate change (net zero } \\
\text { transition) }\end{array}$ \\
\hline Energy white paper: Powering our net zero future & BEIS & 2020 & $\begin{array}{c}\text { Advancement of newer technologies, } \\
\text { job creation, climate change (net zero } \\
\text { transition) }\end{array}$ \\
\hline $\begin{array}{c}\text { Cluster Sequencing for Carbon Capture Usage and Stor- } \\
\text { age Deployment: Phase-1 }\end{array}$ & BEIS & 2021 & $\begin{array}{l}\text { Decarbonisation of economy, leader- } \\
\text { ship in CCUS technologies }\end{array}$ \\
\hline
\end{tabular}

Exploring and developing carbon capture storage technology is presented in official policy documents as being able to bring substantial benefits and help meet the UK's objectives for secure energy supplies, economic growth, lower carbon emissions and leadership in CCUS technologies. In all documents, deploying CCS is presented as supporting the UK to successfully transition in the longer term to a low-carbon economy.

Fossil fuel generating stations are said to contribute to the diversity of energy supply, needed to balance supply and demand and ensure that UK energy grids can cope with increasing amounts of intermittency. In this context, CCS appears as the main technology that can turn high carbon fuels into genuinely low carbon electricity (DECC 2012). The UK government also had originally planned to deploy CCS technology on existing coal power stations. However, due to high costs, length of time beyond 2025 and inefficiency to be adapted to reduce emissions and meet $\mathrm{CO} 2$ abatement requirements, the UK government ruled out mandating Carbon Capture and Storage (CCS) technology to be deployed on existing coal power stations (BEIS 2016, BEIS 2018). There is also an emphasis on the role of CCS on developing new nationally significant energy infrastructure projects.

UK world leadership in CCS technology also appears strongly in official documents as an important policy consideration. At the same time, CCS is presented as driving growth across the UK and providing high skill and well-paying jobs for all sections of society, particularly in the context of creating jobs to support the recovery from COVID19 (BEIS 2020). In terms of supporting economic growth, CCS is seen as providing a decarbonisation service to other countries and benefiting from growing international demand for low carbon products and services (House of Commons 2019). These policy considerations will be taken into account when applying the environmental law principles.

\section{The application of principles of UK environmental law to CCS}

In November 2021, the government enacted the Environment Act 2021 which includes clauses on environmental principles and governance after Brexit. Drawing on the current international and EU environmental principles, the UK government set five 
environmental principles in one place: (i) the principle that environmental protection must be integrated into the making of policy (integration principle); (ii) the principle of preventative action to avert environmental damage; (iii) the precautionary principle, in which there are threats of serious or irreversible environmental damage, a lack of full scientific certainty shall not be used as a reason for postponing cost-effective measures to prevent environmental degradation.; (iv) the principle that environmental damage should as a priority be rectified at source; and (v) the 'polluter pays' principle in which those who cause pollution or damage to the environment should be responsible for mitigation or compensation.

UK environmental principles should be integrated into the making of public policies and their application and interpretation may permeate a great deal of case law. The 'Environmental Principles Duty' created by the Act requires that Ministers must have 'due regard' to the Environmental Principles Policy Statement when making new or updating existing policy. However, at this stage, a final version of the Environmental Principles Policy Statement has not been published yet. Therefore, it is unknow whether environmental principles will serve exclusively as policy drivers behind environmental initiatives, such as CCS, and will play no role in informing the reasoning of a court or if UK environmental principles will inform legal cases and influence decision-making. By the language used in the latest Draft Environmental Principles Policy Statement (2021) in which principles 'cannot dictate policy decisions by Ministers' and the requirement is of only 'due regard', it seems that the direction is leaning towards the former approach. However, the exact obligations entailed by the application of these principles remain unclear.

The Environmental Principles Policy Statement is meant to explain in more detail how these are to be interpreted and provide information as to how they should be applied as per article 17 of the Environment Act 2021. However, the Explanatory Notes related to the Environment Act 2021 makes clear that the principles should be proportionately interpreted and applied.

Proportionate application implies ensuring that action taken on the basis of the principles balances the potential for environmental benefit against other benefits and costs associated with the action. This means that a policy where there is the potential for high environmental damage would require more stringent action than a policy where the potential environmental damage is low. In light of that in order to apply these principles to carbon capture and storage policies in the UK, these policies must be balanced with other considerations, which in the case of CCS are reduction of carbon emissions, security of energy supply, economic growth and technological leadership.

Ministers should also consider the environmental impact of a policy, the value of any mitigating actions, the associated costs and benefits to society of the policy's primary objectives, as well as the financial and economic costs and benefits. However, although due regard to the policy statement on environmental principles should be observed, there is no obligation for a policy to be carried out if doing it would have no significant environmental benefit, or would be in any other way disproportionate to the environmental benefit, as per article 19 of the Environment Act 2021. In this sense, for example, the policy statement does not need to be used to change the direction of a CCS policy, if the environmental impact would be negligible.

Article 19(3) of the Environment Act 2021 also covers certain policies which are excluded from the duty to have due regard to the environmental principles, i.e. the armed forces, defence or national security as well as taxation, spending or the allocation of resources within government. An interesting way to disregard the applicability of environmental principles to CCS policies would be the association of the use of CCS with national security.

Energy security is one of the policy considerations used by the UK government to justify the implementation of CCS. A rich literature associates energy security with national security on the basis that energy products and services are absolutely essential for society to function (Cornell 2009; Luft, Korin, and Gupta 2010; Peoples and Vaughan- 
Williams 2015; Kivimaa and Sivonenac 2021). In this vein, if the use of CCS is considered paramount to ensure energy security, then there may be a possibility that the environmental principles may not apply to CCS policies if these policies are framed in the context of national security, and therefore justifying actions outside the normal bounds of political procedure (Buzan, Waever and de Wilde 1998).

Concerning the applicability of environmental principles under the Act to CCS policies in the UK, the integration principle simply means that environmental protection must be embedded into the making of CCS policies, except in the circumstances stated under article 19 of the Act as explained above. When considering the case of CCS, the remaining four principles may be cause for some discussion and controversy, particularly if the argument to be raised is against the compatibility of CCS with these principles: the principle of preventative action, the rectification at source principle, the precautionary principle and the polluter pays principle.

\subsection{The principle of preventative action and CCS}

Based on the 1992 Rio Declaration, the principle of preventative action requires the adoption of measures intended to prevent damage from arising as an alternative to remedying harm already caused. As per the 2005 arbitral award in the Iron Rhine Arbitration (Belgium $v$ Netherlands) case, the preventative principle requires that 'where development may cause significant harm to the environment there is a duty to prevent, or at least mitigate, such harm'. Based on this concept, minimisation of quantifiable risks could still be seen as preventative.

In international law, the principle's prescriptions range from mere due diligence obligations to obligations to limit emissions or the setting of exposure standards (de Sadeleer 2002). However, the level of risk or damage required to trigger the principle remains unclear. One example of the application of the preventative principle to guide legal reasoning is the joint European case ARCO Chemie Nederland Ltd $v$ Minister van Volkshuisvesting [2000] ECR I-4475 where the court relied on the precautionary and the preventative principles to determine that the concept of waste could not be interpreted restrictively. So far, UK policy documents do not fully explore how the preventative principle operates in the context of protecting the environment. Given that Ministers only need to have due regard to environmental principles, the preventive principle on its own will most probably not provide a broad obligation to prevent environmental harm within English jurisdiction.

Many of the debates about CCS centre on the relationship between risk and the perception of that risk. One may argue that by deploying carbon capture and storage (CCS) and storing carbon dioxide permanently in artificial reservoirs, preventive action is being taken to avert immediate environmental damage with the removal of carbon dioxide from the atmosphere. However, it would be in the public interest if policies aimed at observing the preventative principle focused on the source of pollution by encouraging the development of technologies which prevent the emissions in the first place. Considering that CCS does not avoid the production of harmful emissions but instead buries them, there may be a substantial risk to the environment and burden to future generations. The question is whether there is evidence that CCS can cause substantial harm. If actions can be taken to at least mitigate such harm, then CCS development may be deemed compatible with the principle of preventative action.

One of the issues between CCS and the principle of preventative action lie in the fact that CCS is a new technology. Certainties rest on cumulative experience concerning the degree of risk posed by an activity. Preventive measures are thus intended to avert risks for which the cause and effect relationship is already known (Trouwborst 2009). As there are uncertainties in CCS deployment due to lack of scientific research and actual experience precaution rather than prevention may take priority.

However, UK environmental law principles should be proportionally interpreted and applied. Factors such as the environmental impact of a policy, the value of any mitigating actions and the associated costs and benefits to society of the policy's primary 
objectives must be included in the equation along with the policy considerations given for CCS, i.e. reduction of carbon emissions, security of energy supply, economic growth and technological leadership. The question then is whether support for CCS can be considered proportional when there are other technologies available which can tackle climate change without having to leave a burden for future generations.

\subsection{The rectification at source principle and CCS}

The rectification at source principle means that environmental harm should be prevented at its source rather than rectifying the resulting damage by repairing and restoring the affected environment and compensating for the adverse impact. This principle has not been a central concept employed by English courts in structing its decisions nor has it been widely applied in international and European case law. There is, therefore, a lack of authoritative doctrine around the rectification at source principle.

Considering that CCS does not avoid the production of harmful emissions but instead buries them, there is a threat of possible major damage to the environment and burden to future generations. By burying harmful emissions, a substantial amount of funds is being used to support policies which do not tackle environmental damage at its origin, being, therefore, incompatible with the rectification at source principle. In this sense, CCS policy pays lip-service to the principle of rectifying damage at source since the aim is to tackle the root cause of the problem rather than simply tackling its consequences. In any case, principles are intended to encourage public policies, to allow courts to weigh and reconcile highly divergent interest. In the case in analysis, the balance is between protection of the environment and human health on one side and the policy considerations given to CCS in official policy documents, i.e. reduction of carbon emissions, security of energy supply, economic growth and technological leadership. Following this, taking into account the existence of cleaner alternatives which cause less risk to the environment and support the mentioned policy considerations, such as renewable energy technologies, the backing for carbon capture and storage appears disproportional.

By promoting CCS policies, the focus is on the polluter pays principle where the polluter should pay for damage that it causes to the environment. However, rectifying environmental damage at its source should be a priority.

\subsection{The precautionary principle and CCS}

A consensus has yet to emerge from the vast literature on the precautionary principle with regard to its definition. For some, in international law, the principle has already achieved the status of customary law (McIntyre and Mosedale 1997; Trouwborst 2002). This view is supported by decisions, such as in the case Pulp Mills on the River Uruguay, Argentina v Uruguay [2006] ICJ Rep 113 where Judge Trindade provided a lengthy analysis as to why the precautionary principle is a general principle of international environmental law. This notion, however, was rejected, for example, in the case New Zealand v. Japan; Australia v. Japan (2001) ILR 148 (the Southern Bluefish Tuna cases) under the International Tribunal for the Law of the Sea. For others, the precautionary principle essentially carries a duty of care and should be applied to situations where there is a 'reasonable scientific plausibility' of the risk (de Sadeleer 2002).

The precautionary principle plays a key role in international and European environmental law cases with detailed reasoning about its legal role being given in some cases. The same cannot be stated about UK case law where references to environmental principles are usually brief.

Following the precautionary principle applied in the European case Waddenzee (C127/02) [2005] 2 C.M.L.R. 31, where the most reliable information available leaves obvious doubt as to the absence of possible significant adverse effects on the ecosystem, the benefit of the doubt will favour conservation of the environment.

If the reasoning in Waddenzee is applied to the deployment of CCS in the UK, reliable information leaving obvious doubt as to the absence of possible significant adverse effects 
on the environment would need to be available in order to stop the development and deployment of CCS. In this sense, environmental protection measures should always be adopted unless it can be scientifically proven that particular activities will not cause environmental harm. As such, a long-term storage of CO2, for example, would need to demonstrate acceptably low or no measurable impacts to health, safety, the environment, or existing resources in order to be able to be operational.

Alternatively, as per the UK's argument in the case Ireland v. United Kingdom (2002) 41 ILM 405 (the MOX Plant case) under the International Tribunal for the Law of the Sea, the UK may choose the approach that if there is no evidence of serious harm, the precautionary principle will not apply. This means that in absence of this evidence, it is unlikely that CCS development in the UK would be considered by domestic courts at odds with the precautionary principle. Like the decisions in Preston New Road Action Group v Secretary of State for Communities and Local Government and Cuadrilla Bowland Ltd [2018] EWCA Civ 9 and Gayzer Frackman v. Secretary of State for Communities and Local Government, Lancashire County Council, Cuadrilla Bowland Ltd., Cuadrilla Elswick Ltd 2018 WL 00398402 which challenged the use of hydraulic fracturing, the existence of uncertainty in relevant scientific knowledge would not render unlawful the approach adopted to support CCS when it is satisfied that the relevant regulatory controls would operate effectively to prevent harm to the environment and to human health arising from the proposed development. Since CCUS has been heavily regulated under the Energy Act 2008, Energy Act 2010, Energy Act 2011 and the storage of carbon dioxide (licensing etc) regulations 2010, si 2010/2221, regulatory issues, such as site selection, risk assessment, monitoring \& verification and remediation, have been mostly dealt with.

Other previous case law on energy also demonstrates that when turning to the balance of considerations, decisions have fallen in favour of fossil fuel development due to economic growth and energy security considerations. In Stephensonv Secretary of State for Housing, Communities and Local Government [2019] EWHC 519 (Admin) and Friends of the Earth Ltd $v$ Secretary of State for Communities, Housing and Local Government [2019] EWHC 518 (Admin), for example, there was support for the benefits of on-shore oil and gas development, including unconventional hydrocarbons, for the security of energy supplies and the transition to a low-carbon economy. Therefore, due to the fact that the development and deployment of CCS would itself favour in a way a reduction in carbon emissions, energy security and economic growth it is likely that significant weight will be given to such benefit on the balance of considerations.

However, while there are quantitative methods for assessing CCS risks, the objectivity and reliability of these methods in providing all of the answers can be flawed, particularly if incorrect assumptions are made when undertaking a scientific risk assessment. At the moment, different CCS techniques are at different stages of development, and many are considered to be of doubtful effectiveness at the global scale and not well-researched (UNEP 2012).

Storing carbon emissions raises concerns, such as liability, accounting issues, monitoring and risk of leakage. Many forms of carbon capture and storage keep the $\mathrm{CO} 2$ as gaseous $\mathrm{CO} 2$, which can be challenging to store and transport, and prone to leak back into the air. Damen, Faaij and Turkenburg (2006) suggested that CCS techniques give rise to several risks, i.e., $\mathrm{CO} 2$ leakages due to an escape from the reservoir, $\mathrm{CH} 4$ leakages due to the injection, seismicity due to the injection and could also generate micro earth tremors, ground movement after a subsidence due to pressure changes and displacement of brine as a consequence of the $\mathrm{CO} 2$ injection. All these potential risks may provoke negative effects on the environment. Potential impacts on the environment deriving from possible CO2 leakages related to CCS are getting better understood by the scientific community, however, there is still lack of knowledge and data (Almagro-Pastor et al 2015; BorreroSantiago, DelValls and Riba 2016; Gilfillan et al. 2017; Morkner et al. 2022).

Ultimately, the application of the precautionary principle to CCS will be subject to what is considered significance of risks and the acceptability of scientific evidence as 
'proof' having regard to considerations concerning reduction of carbon emissions, security of energy supply, economic growth and technological leadership.

\subsection{The polluter pays principle and CCS}

The polluter pays principle stems from the notion of punitive measures for those who cause environmental harm, as the costs of pollution prevention, control and remediation should be borne by those who cause pollution. Polluters are responsible for internalisation of external costs, for example in the form of taxes, emission allowances ("cap and trade") and complying with command and control measures, such as prohibitions, restrictions of activity levels, installation of avoidance and abatement devices (Schmidtchen, Helstroffer and Koboldt 2020). While the prevention and precautionary principles follow a preventive logic by seeking to achieve environmental protection before the occurrence of a damage, the polluter pays principle is traditionally seen as a cost allocation mechanism (de Sadeller 2002).

Whilst calculating and apportioning such damages can be difficult, such an approach is necessary to both deter individuals and organisations from polluting excessively and to ensure the burden of repairing such damage lies with those who committed the act rather than the community at large (Costanza et al 1997; Ambec and Ehlers 2016).

The rationale of the polluter pays principle was incorporated in the regulatory framework for carbon capture and storage in the UK. The storage of carbon dioxide (licensing etc) regulations 2010, si 2010/2221, for example, covers the requirements relating to the licensing of $\mathrm{CO} 2$ storage and to the liabilities of the storage operator both during and after the active operation of the store. In cases of leakages, it is the operator's obligation to take necessary health and corrective measures. If the operator fails to take these measures, the authority must do so itself, but the costs must be recovered from the operator.

At first sight the polluter pays principle provides appropriate incentives for the use of CCS as CCS reduces carbon dioxide emissions. Emissions reductions through CCS and the ability to achieve negative emissions in the national energy system was modelled by the UK Energy Technologies Institute (ETI) as essential. Their analysis show that the use of CCS is beneficial on a cost basis, reducing the cost of decarbonisation. Omitting CCS would double the cost of meeting climate change targets to more than $2 \%$ of GDP (ETI 2015).

The question is whether a CCS policy guided by the polluter pays principle, as typically understood, delivers socially and economically optimal solutions to the problem of environmental protection. In a scenario which a company producing electricity from gas would have to cover the full costs of CCS, including the storage costs of $\mathrm{CO} 2$ for decades and insurance for possible leakages, this would make energy production form gas simply very expensive. In another scenario, if damages caused by the storage of carbon dioxide are so great or irreversible that companies could not pay for them or they could only be rectified at considerable costs, then there would be no environmental benefit, social or economic gain. The operator of the storage facility could go bankrupt leaving, as such, the environmental damage as well as the economic costs for the public to pay. The application of PPP, therefore, would not lead to efficient outcomes, leaving room for other policy options to perform better in terms of social, economic, and environmental welfare.

\section{Conclusion}

This paper delved into the application of principles of UK environmental law included in the Environment Act 2021 to carbon capture and storage policies. As principles should be applied in balance with other considerations, firstly, this work sought to examine the policy considerations used to support CCS development in official government documents. In total, four factors were discovered: reduction of carbon emissions, security of energy supply, economic growth and technological leadership.

The analysis then focused on how the principle of preventative action, the precautionary principle, the principle that environmental damage should as a priority be 
rectified at source and the polluter pays principle could be interpreted and applied when taking into account CCS policy considerations. It showed that arguments can be raised concerning the incompatibility of CCS policies with the preventative principle, the rectification at source principle and the precautionary principle. It also revealed that a CCS policy guided by the polluter pays principle may not be cost effective. These findings of the UK case study may be applicable to other countries which have similar domestic environmental laws and legal interpretation, or which have signed and incorporated international agreements containing such principles.

This paper also demonstrated that the exact obligations entailed by the application of these principles remain unclear under English jurisdiction and more light will be shed when the final version of Environmental Principles Policy Statement is published. It seems that the principles' prescriptions will amount to mere due diligence obligations under domestic law. They are to be applied differently in accordance with the level of risk to the environment and in balance with other considerations. Therefore, although CCS initiatives can be at odds with the preventative principle, the rectification at source principle, the precautionary principle and the polluter pays principle, economic and energy security considerations may be prioritised over uncertainties surrounding environmental impacts caused by CCS.

English bodies of case law have not been very prolific in building environmental principles into their case law. It would be interesting to explore the environment case law and the role played by environmental law principles in judicial reasoning and within the English legal systems since the Environment Act 2021 has been enacted in order to examine whether or not and in which ways the courts would be progressive in their reasoning concerning environmental principles. This would also contribute to examining the legality of CCS policies in line with principles of environmental law in the UK and be an example for other legal jurisdictions worldwide.

\section{References}

Almagro-Pastor V. et al. 2015. "Alterations in the macrobenthic fauna from Guadarranque River (Southern Spain) associated with sedimentseawater acidification deriving from CO2 leakage". Mar. Pollut. Bull. 96: 65-75. 10.1016/j.marpolbul.2015.05.044.

Ambec S. and Ehlers L. 2016. "Regulation via the polluter-pays principle". The Economic Journal 126:884-906.

Bhave A. et al. 2017. "Screening and techno-economic assessment of biomass based power generation with CCS technologies to meet $2050 \mathrm{CO} 2$ targets. Applied Energy, 190: 481-489. doi:10.1016/j.apenergy.2016.12.120.

Borrero-Santiago, A.R., DelValls T.A. and Riba I. 2016. "Carbon Capture and Storage (CCS): Risk assessment focused on marine bacteria". Ecotoxicology and Environmental Safety 131: 157-163.

Budinis S. 2021. Direct Air Capture. International Energy Agency.

Buzan B., Waever O., de Wilde J. 1998. Security: A New Framework for Analysis. Lynne Ried, Boulder.

Clarke L. et al. 2014, 'Assessing Transformation Pathways'. In: Edenhofer O. et al. (eds), Climate Change 2014: Mitigation of Climate Change. Contribution of Working Group III to the Fifth Assessment Report of the Intergovernmental Panel on Climate Change. Cambridge University Press.

Committee on Climate Change 2019. Net Zero: The UK's contribution to stopping global warming. Committee on Climate Change. Cornell, P. E. 2009. "Energy and the Three Levels of National Security: Differentiating Energy Concerns within a National Security Context". Connections 8: 63-80.

Costanza R. et al 1997. "The value of the world's ecosystem services and natural capital". Nature 387: 253-260.

Damen K., Faaij A. and Turkenburg W. 2006. "Health, safety and environmental risks of underground CO2 storage - Overview of mechanisms and current knowledge". Climate Change 74: 289-318, 10.1007/s10584-005-0425-9.

Danese, P., Romano, P. and Boscari, S. 2017, "The transfer process of lean practices in multi-plant companies". International Journal of Operations \& Production Management, 37: 1-22.

de Sadeleer, N. 2002. Environmental Principles - From Political Slogans to Legal Rules. Oxford University Press.

Denyer, D. and Tranfield, D. 2009. "Producing a systematic review". In: Buchanan D, Bryman A (eds) The sage handbook of organizational research methods. Sage, London. 
Department for Business, Energy \& Industrial Strategy (BEIS) 2016. Coal generation in Great Britain, The pathway to a low-carbon future: consultation document. BEIS

Department for Business, Energy \& Industrial Strategy (BEIS) 2017. Clean Growth Strategy: Leading the way to a low carbon future. BEIS.

Department for Business, Energy \& Industrial Strategy (BEIS) 2020. Carbon Capture, Usage and Storage: An update on business models for Carbon Capture, Usage and Storage. BEIS.

Department for Business, Energy \& Industrial Strategy August 2020. Carbon capture, usage and storage: A Government Response on potential business models for Carbon Capture, Usage and Storage. BEIS.

Department for Business, Energy \& Industrial Strategy (BEIS) 2022. Projects selected for Phase 1 of the Direct air capture and greenhouse gas removal programme. BEIS. https://www.gov.uk/government/publications/direct-air-capture-and-other-greenhouse-gas-removaltechnologies-competition/projects-selected-for-phase-1-of-the-direct-air-capture-and-greenhouse-gas-removal-programme

Department of Energy and Climate Change 2012. CCS Roadmap: Supporting deployment of Carbon Capture and Storage in the UK. DECC.

Draft Resolution for consideration for the $4^{\text {th }}$ United Nations Environment Assembly (19 February 2019). https://www.politico.eu/wp-content/uploads/2021/08/24/Draft-resolution-for-consideration-for-the-4th-UN-environment-assembly-\%E2\%80\%94-Geoengineering-andits-governance.pdf

ETI 2015. Strategy targets, technologies, infrastructure and investments, preparing the UK for the energy transition. http://www.eti.co.uk/insights/development-insight.

Fridahl M. 2017. "Socio-political prioritization of bioenergy with carbon capture and storage". Energy Policy 104: 89-99. doi:10.1016/j.enpol.2017.01.050

Gilfillan et al. 2017. "Using noble gas fingerprints at the Kerr Farm to assess CO2 leakage allegations linked to the Weyburn-Midale CO2 monitoring and storage project". Int. J. Greenh. Gas Control 63: 215-225. doi:10.1016/j.jjggc.2017.05.015.

Global CCS Institute 2020. Global Status of CCS 2020. Global CCS Institute. https://www.globalccsinstitute.com/wp-content/uploads/2021/03/Global-Status-of-CCS-Report-English.pdf

Haszeldine R.S. et al. 2018. "Negative emissions technologies and carbon capture and storage to achieve the Paris Agreement commitments". Philosophical Transactions A: Mathematical, Physical and Engineering Sciences 376: 1-24

Heffron, R. J. 2018. “Ownership, risk and the law for a CO2 transport network for carbon capture and storage in the European Union”. Journal of Energy \& Natural Resources Law 4:36.

HM Government 2020. The Ten Point Plan for a Green Industrial Revolution: Building back better, supporting green jobs, and accelerating our path to net zero. HM Government.

HM Treasury 2020. National Infrastructure Strategy: Fairer, faster, greener. HM Treasury.

Holland, Lisa 2021. "Boycott threatened over Shell's sponsorship of Science Museum carbon capture exhibition". Sky news. Boycott threatened over Shell's sponsorship of Science Museum carbon capture exhibition | Climate News | Sky News

IEA Greenhouse Gas R\&D Programme (IEAGHG) 2021. "CCUS-related events at COP26". IEAGHG. CCUS-related events at COP26 (ieaghg.org)

Intergovernmental Panel on Climate Change (IPCC) 2005. Carbon Dioxide Capture and Storage. IPCC. srccs wholereport-1.pdf (ipcc.ch)

Intergovernmental Panel on Climate Change (IPCC) 2018. Global Warming of $1.5^{\circ} \mathrm{C}$. IPCC. https://www.ipcc.ch/sr15/

Kemper J. 2015. "Biomass and Carbon Dioxide Capture and Storage: A Review”. International Journal of Greenhouse Gas Control 40.

Kivimaa P. and Sivonenac M. H. 2021. "Interplay between low-carbon energy transitions and national security: An analysis of policy integration and coherence in Estonia, Finland and Scotland”. Energy Research \& Social Science 75: 102024. https://doi.org/10.1016/j.erss.2021.102024.

Luft G., Korin A. and Gupta E. 2010. "Energy security and climate change: A tenuous link" in Sovacool B. K. (ed). The Routledge Handbook of Energy Security. Routledge.

McIntyre O. and Mosedale T. 1997. "The precautionary principle as a norm of customary international law". Journal of Environmental Law 9: 221-241.

Morkner P. et al. 2022. "Distilling data to drive carbon storage insights". Computers \& Geosciences. 158 , 104945. https://doi.org/10.1016/j.cageo.2021.104945.

Nolan C.T. and Garavan T.N. 2016. "Human resource development in SMEs: A systematic review of the literature”. International Journal of Management Reviews 18: 85-107.

Peoples C. and Vaughan-Williams N. Critical Security Studies: An Introduction (Routledge, Abingdon, Oxon 2015) 
Rousseau D.M., Manning J., Denyer D. 2008. Evidence in management and organizational science: assembling the fields full weight of scientific knowledge through syntheses. The Academy of Management Annals 2: 475.

Schmidtchen D., Helstroffer J. and Koboldt C. 2021. "Regulatory failure and the polluter pays principle: why regulatory impact assessment dominates the polluter pays principle". Environmental Economics \& Policy Studies 23: 109-144.

Scotford E. 2017. Environmental Principles and the Evolution of Environmental Law. Hart Publishing.

Thomas N. 2021. "Environment groups question UK's carbon capture push". Financial Times.

Tollefson J. 2019. "Geoengineering debate shifts to UN environment assembly". Nature. https://www.nature.com/articles/d41586-019-007176.

Trouwborst, A. 2002. Evolution and Status of the Precautionary Principle in International Law. Kluwer Law International, London.

Trouwborst A. 2009. "Prevention, Precaution, Logic and Law: The Relationship between the Precautionary Principle and the Preventative Principle in International Law and Associated Questions". Erasmus Law Review 2: 105-128.

United Nations Environment Assembly (UNEA) 2022. "Fifth session of the United Nations Environment Assembly". https://www.unep.org/environmentassembly/unea5

UNEP 2012."Impacts of Climate-Related Geoengineering on Biological Diversity - UNEP/CBD/SBSTTA/16/INF/28 5 April 2012. https://sustainabledevelopment.un.org/content/documents/1740cbd2.pdf

United Nations Framework on Climate Change 2021. Nationally determined contributions under the Paris Agreement. Synthesis report by the secretariat FCCC/PA/CMA/2021/8. https://unfccc.int/documents/306848

Xaver Perrez F. "The Role of the United Nations Environment Assembly in Emerging Issues of International Environmental Law". Sustainability 12: 5680-5700. https://doi.org/10.3390/su12145680 